\title{
DOES INCOME FROM TOURISM SOURCES HAVE AN EQUALISING EFFECT ON INEQUALITY AMONG THE POOR? THE CASE OF LANGKAWI ISLAND, MALAYSIA
}

\author{
A. H. Roslan ${ }^{a}{ }^{*}$, Mohd Saifoul Zamzuri Noor ${ }^{a}$ \\ ${ }^{a}$ Department of Economics, College of Arts and Science, Universiti Utara Malaysia \\ 06010, UUM Sintok, Kedah Darul Aman, Malaysia \\ *Corresponding author, e-mail: ahroslan@uum.edu.my
}

\begin{abstract}
The question posed in this paper is this: is income from tourism sources an equalising or a disequalising factor in the distribution of income among the poor? The examination of this question is imperative since recent literature has suggested that tourism development should be linked with poverty reduction. Unfortunately, this is usually ignored in the formulation of tourism policies and strategies. This paper, therefore, argues that as well as encouraging the poor to participate in the tourism industry, the question of inequality among the poor resulting from their participation in the tourism industry should be considered. In other words, the potential of tourism as a vehicle for scaling up income of the poor should not lead to the widening of inequality among the poor, which could lead to social and political instability. This paper explores this issue by examining the case of the poor households in Langkawi Island, one of the major tourist destinations in Malaysia.
\end{abstract}

Keywords: poverty, income inequality, tourism, Langkawi Island, Malaysia

\section{Introduction}

Recent literature suggests that tourism development should be linked with poverty reduction (Ashley and Roe, 2002; Ashley, Boyd and Goodwin, 2001). It is argued that a vast potential exists for making tourism effectively benefit the poor. This is especially true since the tourism sector is generally labour intensive, inclusive of women and the informal sector. Besides, the tourism sector could also be based on the natural and cultural assets of the poor. Simply put, good opportunities exist for poor households to diversify their income sources through the creation of tourism related employment. Thus, the development of the tourism industry can be an important vehicle for the poor household to increase their income. Indeed, in any area where there is a concentration of tourism activities, the opportunities which arise from tourism development could be central to the economic advancement of the poor households. Consequently, this may lead to a significant reduction in poverty. Thus, the idea of "pro-poor" tourism seems to be appealing and desirable. 
This paper argues that while encouraging the poor to participate in the tourism industry might be plausible and desirable, the question of inequality among the poor should not be ignored. Inequality is regarded as an important aspect of development. Seers (1969) for instance argued that development must address these three major issues - poverty, unemployment and inequality. In his own words (Seers, 1969, p.3):

"The questions to ask about a country's development are therefore: What has been happening to poverty? What has been happening to unemployment? What has been happening to inequality? If all three of these have become less severe, then beyond doubt this has been a period of development for the country concerned. If one or two of these central problems have been growing worse, especially if all three have, it would be strange to call the result "development", even if per capita income has soared."

Therefore, any investigation on inequality among the poor households arising from tourism development is imperative. While the tourism sector might increase the potentials for the poor to diversify their income sources and hence scale up their income level, it might also have significant consequences on income inequality among them. For instance, if opportunities for tourism related employment were skewed towards the "richer" (upper income group) of the poor, then the income inequality among the poor might worsen. On the other hand, if tourism related employment is skewed towards the "poorest" (lower income group) of the poor, then the income inequality among them might improve. Therefore, it should not be taken for granted that the diversification of income from tourism sources among the poor will always has a positive consequences on income inequality among them. Indeed, Elbers, Lanjouw, Mistiaen, Özler and Simler (2004) have cautioned that one should not presuppose that inequality in the poor communities is less severe than the others.

The inequality outcome from the participation of the poor in the tourism industry might have various implications. It could affect the outcome of any development initiative for a given community. Platteau and Gaspart (2003) and Platteau (2004) for instance argue that the outcome of any development program usually depends on income, as well as on asset distribution. They claim that in a poor but highly unequal society, there is tendency for the relatively rich among the group to benefit most from development programs. Furthermore, they also assert that inequality could also undermine collective decision making and social institutions, critical aspects in determining the stability of the society. Thus, while tourism development could be used as a vehicle to help the poor to raise their income, it must not perpetuate inequality and consequently become the destabilising forces within the community. For that reason, the importance of examining the question of whether income from tourism sources is an equalising or a disequalising factor in income inequality among the poor cannot be overemphasized. In this regards, analysis on the impact of the tourism industry on income inequality, particularly among the poor, would be useful to 
policy makers in designing appropriate and better tourism development policy and strategy.

However, while empirical studies on the impact of tourism sector on poverty are vast. Few empirical studies have been done on the impact of tourism on income inequality. One example is Tosun, Timothy and Öztürk (2003) who have investigated the impact of coastal tourism growth on regional inequality in Turkey. Their findings showed that, while tourism had increased the rate of economic growth in Turkey, it had also worsened the equality among regions and classes. Another study Prachvurthy (2005) found that not only did income from tourism contributed only a small percentage in total household income, but income from tourism was also unequally distributed among the villagers.

Unlike the above empirical studies where the focus was on the impact of tourism on regional and total household inequalities, this paper attempts to provide empirical evidence on the impact of tourism on the level of income inequality among the poor households. The study examines the case of poor households in Langkawi Island, Malaysia. This paper is organised as follows. Section I provides the introduction, while section II spells out the research questions. Section III describes the method of the study, and Section IV discusses the findings. Section V is the conclusion.

\section{Research Questions and Objectives}

In general, tourism development contributes positively on the overall growth and development of an economy. Tourism activities usually generate a multiplier effects across many sectors of the economy, as well as providing a wider platform for greater and enhanced inter- and intra-sectoral linkages. Tourism development therefore opens up the potentials for the development of small and medium sized enterprises (SMEs), thereby benefiting the majority of the population. In Malaysia, the number of tourist arrivals had increased from 10.2 million in 2000 to 16.4 million in 2005. During this period, the share of tourism revenue in total earnings from the services account of the balance of payments increased from $32.7 \%$ in 2000 to $43.0 \%$ in 2005 . Indeed, the net contribution of the tourism sector, i.e. taking into account the inflow of foreign tourists and the outflow of local residents travelling abroad, had improved from RM 11.2 billion (Malaysian ringgits) in 2000 to RM 18.1 billion in 2005 (Malaysia: 2006, pp. 193-194). Moreover, corresponding with the increase in tourist arrival, foreign exchange earnings from tourism had also increased at an average annual growth rate of 12.4 percent, from RM17.3 billion in 2000 to RM31.0 billion in 2005. Besides, during the 2000-2005 period, employment in the tourism industry had grown at an average annual growth rate of 2.9 percent, i.e. from 390,600 in 2000 to 451,000 in 2005 (Table 1).

As one of the efforts to attract local and international tourists, the Malaysian government has declared Langkawi Island as one of the major tourist attractions in 
Malaysia (Figure 1). As a measure to boost tourism, Langkawi Island was granted as a duty-free port on the $1^{\text {st }}$ January 1987.The state government of Kedah has also included tourism development as one of the main focus in Kedah Development Action Plan (KDAP) 1991-2000, as well as in Kedah Maju Action Plan (2001-2010). In both plans, Langkawi Island in particular, has been identified as an anchor of the tourist attractions, over other places on the mainland of the state of Kedah. Statistics on tourist arrival in Langkawi Island shows that over the past years the number of tourists, both domestic and international, has been growing steadily though hotel occupancy rates remained at about 60 percent (Table 2).

Table 1 Malaysia: Selected tourism indicators (2000 - 2005)

\begin{tabular}{|l|c|c|}
\hline Indicators & $\mathbf{2 0 0 0}$ & $\mathbf{2 0 0 5}$ \\
\hline Number of tourist arrivals (million) & 10.2 & 16.4 \\
\hline Total tourist receipts (RM Million) & 17.3 & 31.0 \\
\hline Per capita expenditure (RM) & 1696 & 1890 \\
\hline Average length of stay (Nights) & 5.8 & 7.2 \\
\hline Number of hotels & 1492 & 2256 \\
\hline Number of hotel rooms & 124413 & 170873 \\
\hline Average occupancy rate of hotel (\%) & 59.2 & 63.5 \\
\hline Employment & 390600 & 451000 \\
\hline
\end{tabular}

(Source: Government of Malaysia, 2006)

Table 2 Tourist arrival and hotel occupancy rate in Langkawi Island, Malaysia (1986 $-2004)$

\begin{tabular}{|l|c|c|}
\hline Year & Number of arrival & Hotel occupancy rate \\
\hline 1986 & 209763 & n. a. \\
\hline 1990 & 783687 & n. a. \\
\hline 2000 & 1809760 & $60.60 \%$ \\
\hline 2001 & 1919113 & $60.00 \%$ \\
\hline 2002 & 1916451 & $53.80 \%$ \\
\hline 2003 & 1981946 & $53.10 \%$ \\
\hline 2004 & 2179629 & $60.60 \%$ \\
\hline
\end{tabular}

Note: $n$. $a .=$ not available

(Source: Langkawi Development Authority (LADA), 2005)

As Langkawi Island has been proclaimed as one of the major tourist attractions in Malaysia, various tourism-related developments have taken place there to attract tourists. This raises few pertinent questions: (i) Have the poor households in Langkawi Island participated in the tourism industry?; (ii) If they have, what impact does income from tourism sources have on income inequality among them?; (iii) Does income from 
tourism industry has equalising or disequalising effects on income distribution amongst the poor households?

The objective of this paper is to estimate the contribution of income from tourism industry to inequality amongst poor households as well as to determine whether income from tourism is an equalising or a disequalising factor in total inequality among the poor households in Langkawi Island.

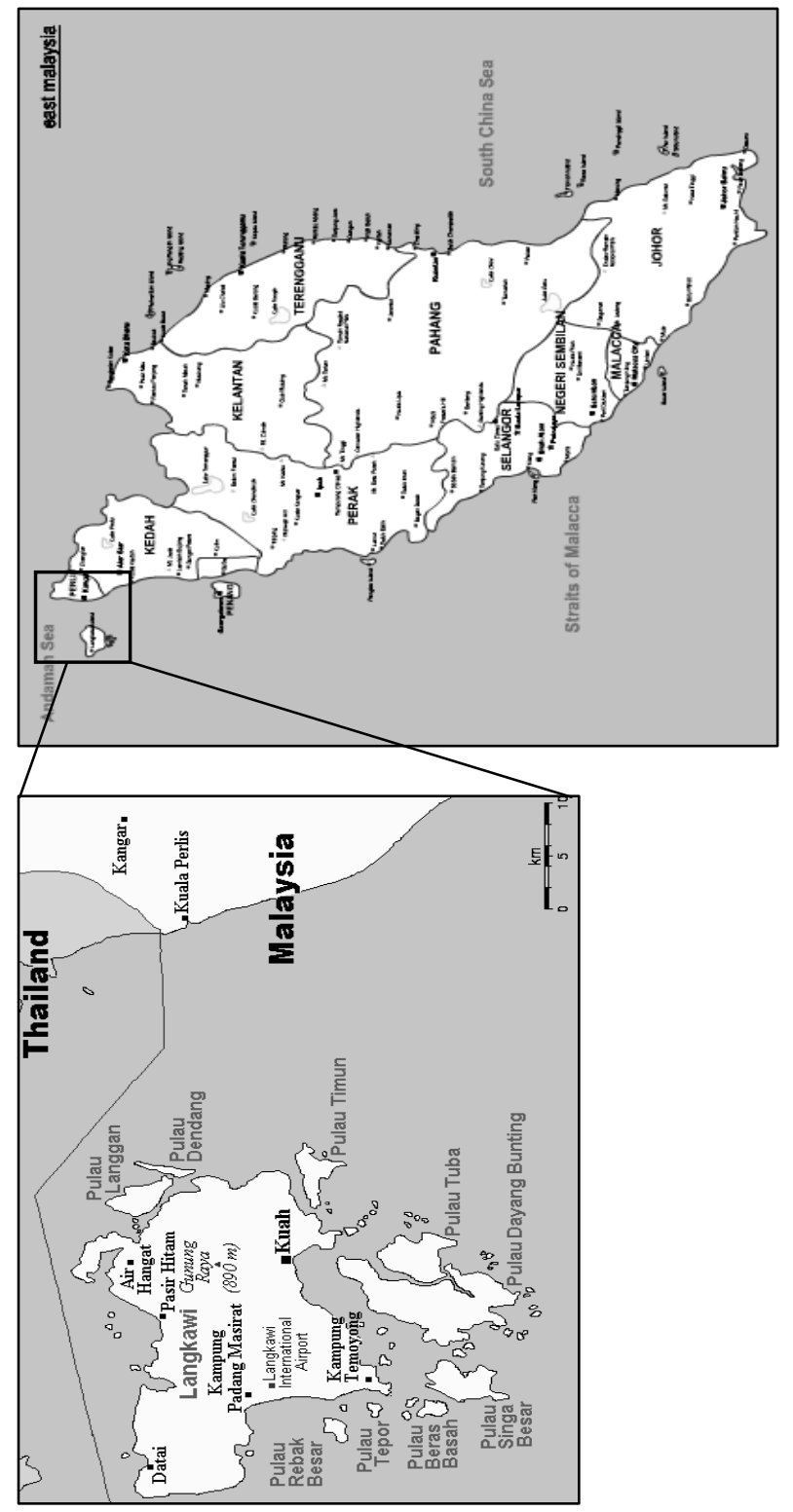

Figure 1 Map of Langkawi Island, Malaysia 


\section{Methodology}

The data and sample

The required data for the study is extracted from questionnaires. A survey was carried out on the poor households in Langkawi Island from October 2005 to December 2005. The list of names and addresses of the poor households was taken from the records of the District Office of Langkawi Island and Kedah Economic Development Authority (KEDA). Based on their latest available records, in 2002 there are a total of 210 poor households registered in Langkawi Island. One hundred and twenty (120) or $57 \%$ of the poor households were selected randomly from the list of the poor households. Face-to-face interviews were carried out with the selected heads of households to gather the required information.

\section{Categorisation of tourism activities}

The question investigated in this paper is whether income from tourism industry has equalising or disequalising effects on income distribution amongst the poor households. Examining this question raises the need to identify income from tourism sources and income from non-tourism sources. Thus, we needed to segregate tourism activities from other (non-tourism) activities. In this regards, how are we going to differentiate income sources from tourism activities and income sources that are not from tourism activities? While the question seems simple, finding the answer appears difficult. The difficulty arises since there is no clear demarcation between tourism activities and non-tourism activities. For instance, income received from working at a hotel or resort in Langkawi Island could be considered as income from tourism activities since most customers of the hotel or resort are mostly tourists rather than locals. However, what about those who work in the transportation industry such as ferry, buses and taxis or those working in restaurants? The answer depends on who their customers are. If most of their customers are tourists, then income received from those activities could be considered as income from tourism. However, if their customers are mainly locals, then income received from those activities could not be considered as income from tourism. How then do we know whether their customers are tourist or not? Even though it is not impossible, getting the information would be a difficult task.

In this study, we solve this problem by using a categorisation provided by the International Labour Organisation (ILO) Committee for the Hotel, Catering and Tourism Sector. We employ the ILO's categorisation since there is no formal definition of tourism provided by the Malaysian tourism authority. The ILO Committee for the Hotel, Catering and Tourism Sector, categorises tourism broadly, as covering these activities (ILO, 2001, p. 5): (i) Hotels, boarding houses, motels, tourist camps, holiday centers; (ii) Restaurants, bars, cafeterias, snack bars, pubs, night clubs, and other similar establishments; (iii) Establishments for the provision of meals and refreshments within the framework of industrial and institutional catering (for 
hospitals, factory and office canteens, schools, aircraft, ships, etc.); (iv) Travel agencies and tourist guides, tourism information offices; and (v) Conference and exhibition centres. Following the ILO's categorisation of tourism-related employment, in this study we classify tourism employment as comprising the following: (i) Hotel, resorts, motels, chalet, inn, and rest house; (ii) Handicraft centre and integrated cultural exhibitions; (iii) Recreational centres; (iv) Theme park; (v) Gallery and museum; (v) Camping/camps; and (vi) Marina/Yacht. Thus, any individual working in one or more of the places listed would be regarded as working in the tourism industry, and hence, the income received from their jobs would be regarded as income from tourism. While the approach could be the source of debate and disagreement, we believe that employing these definitions would serve well our purpose of investigation.

\section{Measure of inequality and decomposition}

With regards to measures of income inequality, we used one of decomposable measures of inequality - the Gini index (Pyatt, Chen and Fei 1980; Shorrocks 1982; Adams 1994; Yao 1997). This approach would allow examination of the contribution of the different sources of income to total inequality. This is particularly sensible to do when household income could be classified according to its various sources, such as income from tourism activities and non-tourism activities. When the total income can be divided into a number of sources, the Gini coefficient measuring the total income inequality can be decomposed into its various sources. Here, we follow a Gini decomposition approach as used by Yao (1997).

Following closely Yao (1997), consider a population that is divided into $n$ groups. Let $m_{i}$ denote the mean income of group $i(i=1,2, \ldots, n), m$ the mean income of the total population, $p_{i}$ the population share of group $i$, and $w_{i}$, where $w_{i}=\frac{p_{i} m_{i}}{m}$, is the income share of group $i$ in total income. Yao (1997) expresses the Gini index measuring total income inequality as follows:

$$
G=1-\sum_{i=1}^{n} p_{i}\left(2 Q_{i}-w_{i}\right), i=1,2, \ldots, n,
$$

where $\sum_{i=1}^{n} p_{i}=1$, and $\sum_{i=1}^{n} w_{i}=1, w_{i}=\frac{p_{i} m_{i}}{m} . \quad Q_{i}=\sum_{k=1}^{i} w_{k}, k=1,2, \ldots, n \quad$ is the cumulative income share from group 1 to group $i$, and $p_{i}$ and $w_{i}$ follow an ascending order of $m_{i}\left(m_{1} \leq m_{2} \leq \ldots \leq m_{n}\right)$. Now, suppose that the total income is derived from $F$ sources. Let $w_{f i}=p_{i} m_{f i} / m_{f}$ denote the income share of group $i$ in the total income 
arising from factor $f(f=1,2, \ldots, F), p_{i}$ is defined as above, $m_{f}$ is the population mean income of factor $f$, and $m_{f i}$ is the mean factor income of group $i$. If $p_{i}$ 's and $w_{f i}$ 's are arranged so that they strictly follow a monotonically ascending order of group mean factor income $m_{f i}$ 's (or $m_{f 1} \leq m_{f 2} \leq \ldots \leq m_{f i} \ldots \leq m_{f n}$ ), the Gini coefficient for income source $f$ is defined as follows:

$$
G_{f}=1-\sum_{i=1}^{n} p_{i}\left(2 Q_{i}-w_{f i}\right) \text {, }
$$

where $\sum_{i=1}^{n} p_{i}=1$, and $Q_{f i}=\sum_{k=1}^{i} w_{f k}$ is the cumulative income share from group 1 to $i$ with $p_{i}$ 's and $w_{i}$ 's following $m_{f 1} \leq m_{f 2} \leq \ldots \leq m_{f i} \ldots \leq m_{f n}$. If $p_{i}$ 's and $w_{f i}$ 's follow an ascending order of group mean total income, $m_{i}$ 's, instead of group mean factor income, $p_{i}$ 's, the same equation can be used to calculate the factor concentration ratio, $C_{f}$, as below:

$$
C_{f}=1-\sum_{i=1}^{n} p_{i}\left(2 Q_{f i}-w_{f i}\right),
$$

with $p_{i}$ 's and $w_{f i}$ 's following $m_{1} \leq m_{2} \leq \ldots \leq m_{n}$. Substituting equation (3) into equation (1), the Gini index can then be decomposed as:

$$
G=\sum_{f=1}^{F} w_{f} C_{f},
$$

where $\sum_{f=1}^{F} w_{f}=\sum_{f=1}^{F} \frac{m_{f}}{m}=1$. In other words, the Gini index of total income is the weighted average of the concentration ratios. Thus, the decomposition of the Gini index only involves the factor concentration ratio, $C_{f}$ 's, and the factor income shares in total income, $w_{f}$. It does not involve the calculation of factor Gini index, $G_{f}$ 's. Dividing the factor concentration ratio, $C_{f}$, with the total Gini index, $G$, gives the relative concentration coefficient, $g_{f}$, which is defined as follows:

$$
g_{f}=\frac{C_{f}}{G} \text {, and } \sum_{f=1}^{F} w_{f} g_{f}=1
$$


The relative concentration ratio, $g_{f}$, shows the effects of income source $f$ on total inequality. If the $g_{f}$ value for an income factor is greater than unity, that income factor is said to be an inequality-increasing factor, which means that, ceteris paribus, an enlarged share of that income factor will lead to an increase in total income inequality. However, if the $g_{f}$ value of an income factor is less than unity, that income factor is said to be an inequality-decreasing factor. The percentage contribution of an income source can then be obtained by multiplying the $w_{f} g_{f}$ value of the income source by 100 .

\section{Results}

A total of 120 poor households were interviewed in our study. The majority of our respondents are middle aged. About one third is between 30 and 39, and one third between 40 to 49 years old, i.e. $60.8 \%$ are between 30 to 49 years old. In terms of gender, $90.2 \%$ of them are male. $45.83 \%$ had their highest education at the high school level. About an equal percentage (44.17\%) had primary school education. Only two of respondents (1.67\%) completed higher education. About $8 \%$ of the respondents did not have any formal education.

\section{Participation in tourism industry}

Table 3 shows that, within the 120 households that we surveyed a total of 184 individuals were employed. Of these, 41 individuals (22.3\%) had a job in the tourism sector. This percentage is quite high compared to national level of only about $4.6 \%$ of total employment (World Travel and Tourism Council, 2006). The high percentage of participation of the poor households in tourism activities in Langkawi Island may be due to the high concentration of tourism activities in a small area, where the mobility of the population is quite limited. As such, the poor might not have much choice but to participate in the tourism industry.

Table 3 Type of occupation of head of household and family members

\begin{tabular}{|l|c|c|c|c|}
\hline Main occupation categories & $\begin{array}{c}\text { Head of } \\
\text { household }\end{array}$ & $\begin{array}{c}\text { Family } \\
\text { members }\end{array}$ & Total & Percentage \\
\hline Tourism & 19 & 22 & 41 & $22.3 \%$ \\
\hline Non-Tourism & 87 & 55 & 143 & $77.7 \%$ \\
\hline Government Servant & 12 & 10 & 22 & $12.0 \%$ \\
\hline Private Sector & 23 & 25 & 48 & $26.1 \%$ \\
\hline Entrepreneur/Business & 19 & 4 & 23 & $12.5 \%$ \\
\hline Fishermen & 28 & 4 & 32 & $17.4 \%$ \\
\hline Rubber Tapper/Farmer & 2 & 1 & 3 & $1.6 \%$ \\
\hline Others & 4 & 11 & 15 & $8.1 \%$ \\
\hline Total & 107 & 77 & 184 & $100.0 \%$ \\
\hline
\end{tabular}


Note: The number of head of household did not add up to 120 since there are 13 head of households who are unemployed, and hence omitted.

With regards to the types of tourism activities that the poor households were involved in, Table 4 shows that $50.0 \%$ engaged in the hotel or resort industry. This is followed by 21.4 percent in travel agencies (or tourist guides or tourist information offices), and $16.7 \%$ in transportation (land and sea transportation). There are only three individuals (or $7.1 \%$ ) who were participating in handcrafts related activities.

Table 4 Participation of poor households in tourism industry by types of tourism activities

\begin{tabular}{|l|c|c|}
\hline Types of tourism activities & Frequency & Percentage \\
\hline Restaurant/Bar/Cafeteria/Snack bar/Pub/Night club & 1 & $2.44 \%$ \\
\hline $\begin{array}{l}\text { Travel Agencies/Tourist Guides/Tourism } \\
\text { Information offices }\end{array}$ & 9 & $21.95 \%$ \\
\hline Handcraft - business/entrepreneur & 3 & $7.32 \%$ \\
\hline Marina & 1 & $2.44 \%$ \\
\hline Hotel/Resort & 20 & $48.78 \%$ \\
\hline Land transportation & 2 & $4.88 \%$ \\
\hline Sea transportation & 5 & $12.20 \%$ \\
\hline Total & 41 & $100.00 \%$ \\
\hline
\end{tabular}

Structure and distribution of household income

Table 5 shows the structure of income of poor households at Langkawi Island. It shows that about one quarter (25.32\%) of their total income is comes from the tourism sector and three quarters (74.68\%) is from the non-tourism sector. The percentage of income derived from tourism is considered high if compared to national level. In 2006, the contribution of tourism in Malaysia's GDP was forecast at $10.8 \%$ (World Travel and Tourism Council, 2002).

Table 5 Structure of total household income of the poor household

\begin{tabular}{|l|c|c|c|}
\hline \multirow{2}{*}{} & \multicolumn{2}{|c|}{ Sources of income } & \multirow{2}{*}{ Total } \\
\cline { 2 - 3 } & Tourism & Non-Tourism & \\
\hline Total (RM) & 32172 & 94877 & 127049 \\
\hline Share in total household income (\%) & $25.32 \%$ & $74.68 \%$ & $100.00 \%$ \\
\hline
\end{tabular}

Table 6 shows the distribution of total household income by income sources. The largest number of households (41\%) receives a total household income of between RM 501 and RM 1000 per month, while about 21\% receive between RM 1001 and RM 1500 . $18 \%$ receive RM 500 or less per month. It is interesting to note that $20 \%$ of poor 
households receive more than RM 1500 per month, which is relatively high. Indeed, $4 \%$ of poor households receive more than RM 3000 per month. The average total household income received by poor households is RM 1059 per month (Table 7).

Table 6 Distribution of total household income (RM/Month)

\begin{tabular}{|l|c|c|}
\hline Income range (RM/Month) & Number & Percentage \\
\hline 500 or less & 22 & $18.3 \%$ \\
\hline $501-1000$ & 49 & $40.8 \%$ \\
\hline $1001-1500$ & 25 & $20.8 \%$ \\
\hline $1501-2000$ & 12 & $10.0 \%$ \\
\hline $2001-2500$ & 4 & $3.3 \%$ \\
\hline $2501-3000$ & 3 & $2.5 \%$ \\
\hline More than 3000 & 5 & $4.2 \%$ \\
\hline N & 120 & $100.0 \%$ \\
\hline
\end{tabular}

Table 7 Descriptive statistics of total household income (RM/Month)

\begin{tabular}{|l|c|}
\hline Mean & 1058.7 \\
\hline Minimum & 130 \\
\hline Maximum & 5500 \\
\hline Std. deviation & 825.7 \\
\hline $\mathrm{N}$ & 120 \\
\hline
\end{tabular}

As far as the income from the tourism sources is concerned, $44 \%$ received household incomes of between RM 501 and RM 1000 per month, while about onethird (34\%) of them receive RM 500 or less per month (Table 8). Nearly one tenth (9.8\%) received household income of RM 1501 to RM 2000 per month. The average income of those participating in the tourism industry is RM 785 per month (Table 9).

Table 8 Distribution of income received from tourism sources (RM/Month)

\begin{tabular}{|l|c|c|}
\hline Income range (RM/Month) & No. & Percentage \\
\hline 500 or less & 14 & $34.1 \%$ \\
\hline $501-1000$ & 18 & $43.9 \%$ \\
\hline $1001-1500$ & 5 & $12.2 \%$ \\
\hline $1501-2000$ & 4 & $9.8 \%$ \\
\hline $2001-2500$ & 0 & $0.0 \%$ \\
\hline $2501-3000$ & 0 & $0.0 \%$ \\
\hline More than 3000 & 0 & $0.0 \%$ \\
\hline $\mathrm{N}$ & 41 & $100.0 \%$ \\
\hline
\end{tabular}


Table 9 Descriptive statistics of income received from tourism sources (RM/Month)

\begin{tabular}{|l|c|}
\hline Mean & 784.7 \\
\hline Minimum & 120 \\
\hline Maximum & 1800 \\
\hline Std. deviation & 441.2 \\
\hline N & 41 \\
\hline
\end{tabular}

Impact of tourism activities on inequality

Table 10 shows the Gini coefficient for each income source - tourism and nontourism, as well as for the total household income. The Gini coefficient for the total household income is 0.364 , which implies that the distribution of total income amongst the respondents appears to be equal. The Gini coefficient is higher, i.e. 0.496, when income from tourism sources is subtracted from the total household income. This indicates that without income from tourism sources, income distribution is worse than if there were income from tourism sources. It is also worth mentioning that income from tourism sources is very unequally distributed amongst the poor households, as shown by the Gini coefficient of 0.762 .

Table 10 Income inequality by income sources

\begin{tabular}{|l|c|}
\hline Sources of income & Gini coefficient \\
\hline Income from tourism & 0.762 \\
\hline Non-Tourism income & 0.496 \\
\hline Income from all sources (Total income) & 0.364 \\
\hline
\end{tabular}

However, it must be noted that while Table 10 seems to imply that the opportunity for deriving income from tourism sources improve the overall income inequality, we cannot conclude this with certainty since the Gini coefficient is calculated independently for each sources of income, and hence, the Gini coefficient for each income sources is not added up to the total (overall) Gini coefficient. Thus, this perception could be misleading. To examine the contribution and the impact of inequality in tourism income on the total income inequality, we need to decompose the total (overall) Gini coefficient. This would allow us to examine more clearly the contribution and the impact of inequality in tourism income on the total income inequality, since the contribution of any income source to total inequality does not only depend on the degree (magnitude) of inequality of each source as calculated in Table 10 , but also on the relative importance (share) of that income source in total household income. Hence, there is a possibility that while income from tourism sources was highly unequally distributed, its contribution to total inequality was not as large as the 
non-tourism sources since the importance (share) of income from tourism sources in total household income is relatively small compared to non-tourism sources as shown in Table 5.

The decomposition of the Gini index as suggested by Yao (1997) allow us to examine directly which income source served to increase or decrease inequality. This attribute of income source could be identified by looking at the relative concentration coefficient $\left(g_{f}\right)$ derived from the Gini inequality decomposition. As mentioned earlier, a relative concentration coefficient $\left(g_{f}\right)$ of more than the value of unity (one) implies that an income source had a disequalising (negative) effect on total inequality, while a value less than unity (one) implies that the income source had an equalising (positive) effect on inequality. Table 11 shows the results of our Gini decomposition exercise.

Table 11 Summary results of Gini decomposition (Yao, 1997) by income sources

\begin{tabular}{|c|c|c|c|c|c|c|c|c|}
\hline $\begin{array}{l}\text { Income } \\
\text { sources }\end{array}$ & $m_{f}$ & $w_{f}$ & $G_{f}$ & $C_{f}$ & $w_{f} C_{f}$ & $g_{f}=\frac{C_{f}}{G}$ & $w_{f} g_{f}$ & 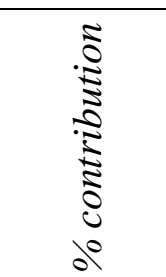 \\
\hline Tourism & 268.10 & 0.2532 & 0.7623 & 0.3848 & 0.0974 & 1.0574 & 0.2678 & $26.78 \%$ \\
\hline Non-Tourism & 790.64 & 0.7468 & 0.4958 & 0.3568 & 0.2665 & 0.9805 & 0.7322 & $73.22 \%$ \\
\hline Total & 1058.74 & 1.0000 & 0.3639 & 0.3639 & 0.3639 & 1.0000 & 1.0000 & $100.00 \%$ \\
\hline
\end{tabular}

It shows that the percentage of income share of tourism source is $25.32 \%$, while its contribution to total inequality is $26.78 \%$. This implies that income from tourism sources has an disequalising effect on inequality since its share in total income is smaller than its share in total inequality. This is confirmed by the relative concentration coefficient $\left(g_{f}\right)$ for tourism sources, where the value is more than one. Thus, ceteris paribus, enlarged share of income from tourism will lead to an increase in total income inequality.

\section{Summary and Conclusion}

The demand for tourism will usually generate a multiplier effect across many sectors, and thus widen and deepen the inter- and intra-sectoral linkages of the economy. It opens up the potential for earning higher incomes, particularly through the SMEs, thereby benefiting majority of the lower income groups. Besides, tourism sector is one of the key foreign exchange earner for many countries, and thus strengthening 
the services account of the balance of payments. Therefore, the tourism sector is commonly perceived to have a positive impact on the overall economy.

While the development of the tourism sector could bring a positive impact on the economy in aggregate, the specific impact at the micro level could be different. Thus, a study on the impact of the tourism sector at a micro level would not only be informative, but also useful. Here, we examined the impact of tourism sector on the poor households in one of a popular tourist destination of Malaysia, i.e. the Langkawi Island.

The results from our study show that, even without significant deliberate effort from the government to encourage the poor to be involved in the tourism industry, a relatively high percentage (22\%) of poor households in Langkawi Island do participate in the tourism industry. Besides, income from tourism is found to constitute about $25 \%$ of their total household income. This finding shows that even though the poor in Langkawi Island have a relatively low level of education, it did not hinder them from participating in the tourism industry. Most likely these poor households are concentrated in low paid jobs, as shown by our finding that $44 \%$ of them actually receive incomes between RM 501 and RM 1000 per month from the tourism sources.

This study also shows that income received from tourism is a disequalising factor rather than an equalising one in income distribution among poor households. This suggests that opportunities that arise from tourism development in Langkawi Island are biased towards the relatively richer rather than to the poorer of the poor households. Thus, while the tourism industry in Langkawi Island might "trickle down" its benefits to the poor households, it is not evenly distributed. In fact, as this study shows, an enlarge share of income from tourism may well worsen the overall income distribution among the poor households. Therefore, a pro-poor tourism, i.e. encouraging the poor to participate in the tourism industry, would not be enough. To successfully reduce poverty and simultaneously improve inequality, policy makers and development agencies need to look at the possibility of making tourism work not only for the poor, but to ensure that the poorest among the poor may get better employment or business opportunities. Only then, will opportunities opened up by the tourism industry will not only work for the poor and reduce poverty in general, but also improve income equality within the society as well.

\section{References}

1. Ashley, C., D. Roe (2002) Making tourism work for the poor: strategies and challenges in Southern Africa. Development Southern Africa, 19(1), pp. 61-82

2. Ashley, C., D. Roe, H. Goodwin (2001). Pro-poor tourism strategies: making tourism work for the poor. A review of experience. London: Overseas Development Institute (ODI), International Institute for Environment and Development (IIED), and Center for Responsible Tourism (CRT) 
3. Elbers, C., P. F. Lanjouw, J. A. Mistiaen, B. Özler, and K. Simler (2004) On the unequal inequality of poor communities. The World Bank Economic Review, 18(3), pp. 401-421

4. Government of Malaysia (2006). Ninth Malaysia plan, 2006-2010. Kuala Lumpur: National Printers

5. International Labour Organisation (ILO) (2001) Human resources development, employment and globalization in the hotel, catering and tourism sector. Report for discussion at the Tripartite Meeting on Human Resources Development, Employment and Globalization in the Hotel, Catering and Tourism Sector. Geneva, 26 April 2001. International Labour Office (ILO), Geneva

6. Kedah State Economic Planning Unit (1994) Kedah development action plan 1991-2000. Alor Setar: Kedah State Economic Planning Unit

7. Kedah State Economic Planning Unit (2001) Kedah maju action plan 20012010. Alor Setar: Kedah State Economic Planning Unit

8. Langkawi Development Authority. (2005). Unpublished data

9. Platteau, Jean-Philippe (2004) Monitoring elite capture in communitydriven development. Development and Change, 35(2), pp. 223-246

10. Platteau, Jean-Philippe, and Frederic Gaspart. (2003) The 'elite capture' problem in participatory development. Working Paper 253/14. FUNDP, University of Namur, Belgium

11. Prachvuthy, M. (2005) Poverty and tourism: income distribution-the case of Chambok community-based ecotourism development, Kirirom National Park, Kompong Speu Province, Cambodia. The workshop on "Mekong tourism: Learning across borders", Social Research Institute, Chiang Mai University, 25 February 2005. URL:http://www.rockmekong.org/events/html_file/socialResearchCHM/files/Vuthy.p df (Accessed on February 15, 2008)

12. Seers, D. (1969) The meaning of development. International Development Review, 11(4), pp. 2-6

13. Sen, A. (1997) On Economic Inequality (Expanded edition with a substantial Annexe by James E. Foster and Amartya Sen). Oxford: Clarendon Press

14. Tosun, C., D. J. Timothy, Y. Öztürk, (2003). Tourism growth, national development and regional inequality in Turkey. Journal of Sustainable Tourism, 11(2\&3), pp. 133-161

15. World Travel \& Tourism Council (WTTC) (2002) The impact of travel and tourism on jobs and the economy. London: WTTC.

16. Yao, S. (1997) Decomposition of Gini coefficient by income factors: a new approach and applications. Applied Economic Letters, 4(1), pp. 27-31

RECEIVED: 29.12.2007

ACCEPTED: 13.06 .2008 